\title{
Geo(im)pulse
}

\section{Stable isotopes, niche partitioning and the paucity of elasmosaur remains in the Maastrichtian type area}

\author{
Anne S. Schulp ${ }^{1,2,3, *}$, Renée Janssen ${ }^{3}$, Remy R. van Baal ${ }^{3}$, John W.M. Jagt ${ }^{2}$, Eric W.A. Mulder ${ }^{2,4}$ \\ \& Hubert B. Vonhof ${ }^{3,5}$
}

1 Naturalis Biodiversity Center, P.0. Box 9517, 2300 RA Leiden, The Netherlands

2 Natuurhistorisch Museum Maastricht, De Bosquetplein 6-7, 6211 KJ Maastricht, The Netherlands

3 Faculty of Earth and Life Sciences, Vrije Universiteit Amsterdam, De Boelelaan 1085, 1081 HV Amsterdam, The Netherlands

4 Natura Docet Wonderryck Twente, Oldenzaalsestraat 39, 7591 GL Denekamp, The Netherlands

5 Max Planck Institute of Chemistry, Hahn-Meitnerweg 1, 55128 Mainz, Germany

* Corresponding author. Email: anne.schulp@naturalis.nl

Manuscript received: 9 November 2015, accepted: 4 June 2016

\section{Abstract}

Remains of elasmosaurid plesiosaurs are exceedingly rare in the type-Maastrichtian strata (Late Cretaceous, southeast Netherlands and northeast Belgium), in stark contrast to relatively common skeletal remains of mosasaurs. Here, we present an analysis of $\delta^{13} \mathrm{C}$ stable isotope values for tooth enamel of two elasmosaur teeth from the type Maastrichtian. The $\delta^{13} \mathrm{C}$ signal is a proxy for foraging area, trophic level and diving behaviour, the net value of which in these rare elasmosaurs turns out to be not noticeably different from that for the much commoner mosasaurs in the type Maastrichtian. Therefore, the rarity of elasmosaurs in the area probably reflects a primary near-absence of such reptiles during the latest Cretaceous, rather than a taphonomic artefact.

Keywords: $\delta^{13} \mathrm{C}$, Elasmosaurs, Late Cretaceous, Mosasaurs, northwest Europe, Plesiosaurs

\section{Introduction}

Type-Maastrichtian strata (southeast Netherlands and northeast Belgium) preserve a rich and diverse record of Late Cretaceous (c. 67-66 Ma) marine life (Mulder, 2003). Aquatic tetrapods from these levels are represented by several taxa of mosasaurs and marine turtles, as well as elasmosaurs, birds and crocodylians. While two species of mosasaur are relatively common, three others - the Globidensines - are only rarely encountered (Schulp et al., 2013, and references therein) and discoveries of elasmosaur, bird and crocodile remains are equally few and far between (Mulder, 2003; Dyke et al., 2008). In contrast, isolated bones of carapaces and appendicular skeletons of marine turtles are comparatively common (Janssen et al., 2011). By comparing the $\delta^{13} \mathrm{C}$ stable isotope signal derived from the tooth enamel of mosasaurs and elasmosaurs, we here attempt to identify the underlying cause(s) of the observed pattern of relative abundance and rarity of mosasaurs and elasmosaurs, respectively, in the record for the type Maastrichtian.

\section{Material and methods}

Vertebrates from the type Maastrichtian are relatively well known, and the sites yielding these fossils have been extensively sampled for over two centuries; Mulder (2003) presented a detailed overview of the type-Maastrichtian tetrapod fauna. Even though there have been additions to this during the following decade (e.g. Martin et al., 2005; Schulp, 2006; Dyke et al., 2008; Schulp et al., 2008), the basic pattern as outlined by Mulder (2003) still stands. Here we build our analysis on Mulder's semi-quantitative survey of collections (Mulder, 2003; see also Kuypers et al., 1998) and recent work on stable isotope geochemistry in mosasaurs (Schulp et al., 2013), 
to which new data on two elasmosaur teeth are added. Material and methods for stable isotope analyses, performed at Amsterdam VU University, are identical to those outlined in Schulp et al. (2013) and are not repeated here. To the mosasaur dataset analysed in that paper, we add data on tooth enamel of two isolated teeth of Elasmosauridae indet., housed in the collections of the Natuurhistorisch Museum Maastricht (NHMM 003824, NHMM MND.K.20.01.802; see Fig. 1A; for more details see Mulder, 1990, 2003). Both specimens come from the Maastrichtian type area: to be more precise, from Kunrade and from the Emael Member at the Sint Pietersberg near Maastricht, respectively.

\section{Paucity of elasmosaur remains}

By Mulder's (2000) count, the entire type-Maastrichtian elasmosaur record then known comprised seven vertebrae and a handful of teeth, which is exceedingly meagre considering the more than two centuries of intensive collecting effort invested. In view of the fact that the $\delta^{13} \mathrm{C}$ signal as preserved in tooth enamel presents a proxy representing the combined signal of diet, foraging area and diving behaviour (Clementz \& Koch, 2001; Biasatti, 2004; Robbins et al., 2008; Schulp et al., 2013, and references therein), the signal as preserved in elasmosaur teeth from the type Maastrichtian could potentially yield information on how foraging area and niche exploitation of elasmosaurs compares to mosasaurs. A possible explanation for the rarity of elasmosaurs, as compared to mosasaurs, in the type Maastrichtian might well revolve around mutually exclusive resource partitioning, with foraging areas much further offshore preferentially exploited by elasmosaurs - this hypothesis we put to the test in the present note.

We fully realise that the near-absence of elasmosaur teeth in the type-Maastrichtian record has an impact on the size of the available dataset as well. This limited number of fossil remains calls for additional restraint in destructive testing. At this point, only two samples could be analysed from two teeth available to us.

\section{Results and discussion}

The two enamel samples analysed yielded $\delta^{13} \mathrm{C}$ values of $-10.16 \%$ and $-12.50 \%$ (NHMM MND.K.20.01.802 and NHMM 003824, respectively). Both values fall within the range observed for co-occurring mosasaurs (Schulp et al., 2013) and as such do not a priori set elasmosaurs apart from mosasaurs in terms of ecological proxies discussed above. This is similar to the pattern observed by Strganac et al. (2015) in the Late Cretaceous of Angola, the only other published study we are aware of in which the $\delta^{13} \mathrm{C}$ signal of multiple samples of plesiosaurs and a range of mosasaur taxa from the same ecosystem are compared.
The isotope values as obtained from the Maastricht specimens are more than $10 \%$ lower than those of well-preserved belemnite guards ( 0 to $+2 \%$; Vonhof et al., 2011) or shark tooth enamel $(+4.6 \%$; van Baal et al., 2013) from the same stratigraphic sequences. The one other taxon that has $\delta^{13} \mathrm{C}$ values close to the mosasaurs and elasmosaurs is the marine turtle Allopleuron hofmanni (-7.1\%; van Baal et al., 2013), which emphasises that so far only lung-breathing taxa have values below a $\delta^{13} \mathrm{C}$ value of $-5 \%$ Vienna Pee Dee Belemnite (VPDB).

Figure $1 \mathrm{~A}$ presents an attempt to map and summarise the three main drivers in $\delta^{13} \mathrm{C}$ values that are preserved in tooth enamel in a single palaeoenvironmental/palaeoecological framework: (1) every trophic step pushes $\delta^{13} \mathrm{C}$ values to become c. $1 \%$ more enriched; (2) through the Bohr effect, deep diving results in more depleted values; and (3) an offshore and/or deepwater foraging area also results in more depleted values (Clementz \& Koch, 2001; Biasatti, 2004; Schulp et al., 2013, and references therein). Taken together, these three drivers allows us to draw, at any given trophic level, a series of diagonal isolines for $\delta^{13} \mathrm{C}$ values in the diagram, combining diving behaviour and foraging areas which, in turn, permits pinpointing the position that the different species occupied in the ecosystem. The exact slope and position of the isolines in this schematic diagram obviously cannot be quantified, particularly since palaeodepth is greatly exaggerated in comparison to the lateral extent of the platform, but the general geometry and values encountered in the nearshore and offshore area are expected to have been roughly along the lines illustrated.

We first discuss the position occupied by mosasaurs, before evaluating that potentially taken by the two elasmosaur samples in this scenario. From a taphonomic point of view, we wish to stress that the type-Maastrichtian strata provide only a narrow window into a more extensive ecosystem, ranging from a nearshore/reefal setting (far right side of the diagram; southeast) to a much deeper-water setting (left side of the diagram; northwest). With only the median portion of the diagram directly represented in the type-Maastrichtian fossil record, material washed down from the reef, transported by 'float and bloat', and the occasional (accidental) immigrant, could account for rare occurrences in this record, and vice versa, rare occurrences in the fossil record as preserved in the central part of the diagram provide an occasional glimpse of the fauna in more distant reaches of the area.

Stable isotope analysis suggests the small, durophagous mosasaur Carinodens belgicus to have occupied a more nearshore/shallow-water niche (right side of the diagram). In all likelihood, this species foraged in the more nearshore, even shallower, reaches of the basin, towards what is now the German border. This pattern is in some ways reflected in the relative abundance of Carinodens at the various quarries and outcrops. Whereas the westernmost, relatively deepwater/offshore quarries (e.g. ENCI, CBR-Romontbos and CBR-Lixhe; see Schulp, 2005, fig. 1A) have yielded remains of several mosasaur taxa, 
A
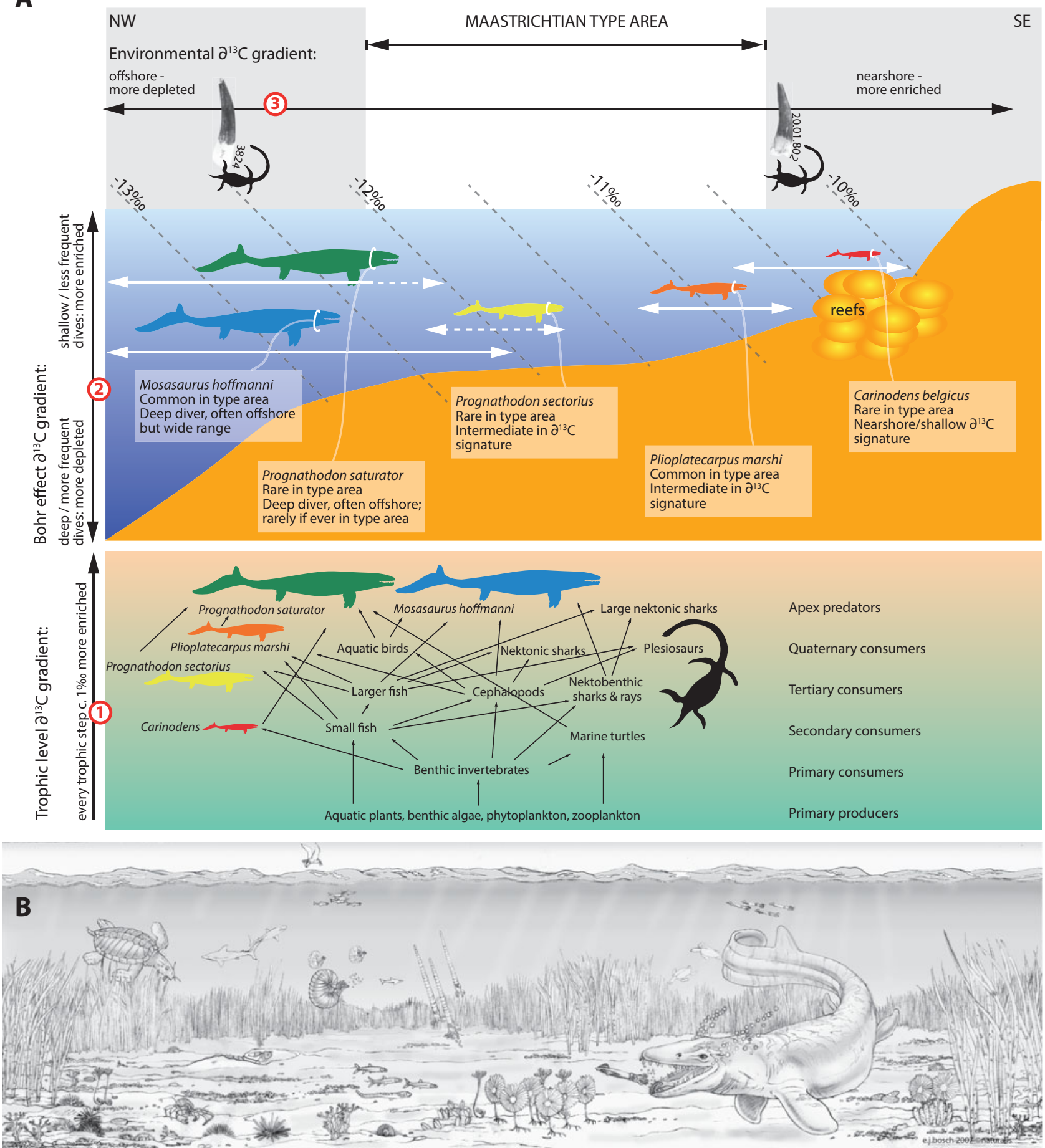

Fig. 1. (A) Tooth enamel $\delta^{13} \mathrm{C}$ in the type-Maastrichtian ecosystem in mosasaurs and elasmosaurid plesiosaurs. The $\delta^{13} \mathrm{C}$ values are determined by (1) trophic level, (2) diving behaviour and (3) foraging area. The marine Maastrichtian food web was expanded following Sørensen et al. (2013); mosasaur silhouettes after Lindgren et al. (2013). (B) A near-typical, type-Maastrichtian 'seascape', with elasmosaurs conspicuously absent. However, the presence of Prognathodon saturator (on the right) must have been a relatively rare event in these shallow waters. Reconstruction by Erik Jan Bosch (Naturalis, Leiden), with input from NHMM (JWMJ).

occurrences of Carinodens (by no means statistically significant given the small number of specimens) appear to be commoner in the easternmost (more nearshore) outcrops of the type Maastrichtian (Schulp, 2005). Conversely, the sole records of Prognathodon saturator (Fig. 1B, right), a mosasaur presumably preferring a more deepwater/offshore habitat (Schulp \& Jagt, 2015), are all from the more westerly outcrops in the Sint Pietersberg area. 
In a reconstructed Late Cretaceous marine food web (based on Sørensen et al., 2013, with the five mosasaur taxa from the type Maastrichtian inserted; Fig. 1A), both elasmosaur samples analysed and mosasaurs occupy a position that ranges from secondary consumers up to apex predator, which could account for a range of c. $3 \%$ difference in $\delta^{13} \mathrm{C}$ value at most. It must be emphasised that, although (large) apex predators would be expected to display enriched values in comparison to predators lower in the food chain, the reverse is observed here, with larger animals generally displaying more depleted values. This difference must, then, be further explained by foraging area and diving behaviour, the combined signal of which clearly more than offsets the expected enrichment by trophic level.

In terms of tooth shape, which is an indicator of dietary specialisation (e.g. Massare, 1987), the curved, pointed teeth of elasmosaurid plesiosaurs find their nearest analogue in terms of tooth shape in the mosasaur Plioplatecarpus marshi. The $\delta^{13} \mathrm{C}$ values observed in the two elasmosaur samples do indeed overlap with values obtained for that presumably piscivorous and relatively common taxon and those of the (much rarer) mosasaur Prognathodon sectorius.

Assuming that the biochemical pathways in enamel development are similar in mosasaurs and plesiosaurs, the two $\delta^{13} \mathrm{C}$ values obtained from the elasmosaur teeth $(-10.16$ and $-12.50 \%$ ) place the latter well within the range occupied by mosasaurs in the diagram (Fig. 1A), in other words, in an ecological setting which would be conducive to fossilisation in a similar fashion to that for co-occurring mosasaurs. Clearly, this is not reflected in the fossil record, and it would appear more likely that the observed rarity of elasmosaurs in the type-Maastrichtian ecosystem is a genuine reflection of the near-absence of these animals in the wider area (Fig. 1B), rather than a taphonomic artefact on a more local scale with elasmosaurs occupying a more offshore habitat.

This near-absence of elasmosaurs in the epicontinental shallow 'Maastricht sea' is in accordance with the observation that a relative abundance of these animals is recorded solely in Late Cretaceous marginal seas such as the coast of California and in the Maastrichtian of Morocco, where the presence of a nearby abrupt continental slope coincided with upwelling of nutrientenriched water, which led to high biomass. Apparently, this was the sine qua non for open-water predators such as elasmosaurs (Mulder et al., 2000).

\section{Acknowledgements}

Many thanks to Suzan Verdegaal (Vrije Universiteit Amsterdam) for help in sample analysis, to Erik Jan Bosch (Naturalis, Leiden), who prepared Figure 1B and Sven Sachs (NaturkundeMuseum Bielefeld, Germany) for his helpful review of an earlier version of the manuscript.

\section{References}

Biasatti, D.M., 2004. Stable carbon isotopic profiles of sea turtle humeri: implications for ecology and physiology. Palaeogeography, Palaeoclimatology, Palaeoecology 206: 203-216.

Clementz, M.T. \& Koch, P.L., 2001. Differentiating aquatic mammal habitat and foraging ecology with stable isotopes in tooth enamel. Oecologia 129: 461472.

Dyke, G., Schulp, A.S. \& Jagt, J.W.M., 2008. Bird remains from the Maastrichtian type area (Late Cretaceous). Netherlands Journal of Geosciences 87: 353358.

Janssen, R., van Baal, R.R. \& Schulp, A.S., 2011. On the taphonomy of the late Maastrichtian (Late Cretaceous) marine turtle Allopleuron hofmanni. Netherlands Journal of Geosciences 90: 187-196.

Kuypers, M.M.M., Jagt, J.W.M., Peeters, H.H.G., de Graaf, D.Th., Dortangs, R.W., Deckers, M.J.M., Eysermans, D., Janssen, M.J. \& Arpot, L., 1998. Laat-kretaceische mosasauriers uit Luik-Limburg. Nieuwe vondsten leiden tot nieuwe inzichten. Publicaties van het Natuurhistorisch Genootschap in Limburg 41: 4-47.

Lindgren, J., Kaddumi, H.F. \& Polcyn, M.J., 2013. Soft tissue preservation in a fossil marine lizard with a bilobed tail fin. Nature Communications doi:10.1038/ncomms3423

Martin, J.E., Case, J.A., Jagt, J.W.M., Schulp, A.S. \& Mulder, E.W.A., 2005. A new European marsupial indicates a Late Cretaceous high-latitude transatlantic dispersal route. Journal of Mammalian Evolution 12: 495-511.

Massare, J., 1987. Tooth morphology and prey preference of Mesozoic marine reptiles. Journal of Vertebrate Paleontology 7: 121-137.

Mulder, E.W.A., 1990. Ein Elasmosaurierzahn aus der oberen Kreide des St. Pietersberges bei Maastricht, Süd-Limburg, Niederlande. Paläontologische Zeitschrift 64: 145-151.

Mulder, E.W.A., 2003. On latest Cretaceous tetrapods from the Maastrichtian type area. Publicaties van het Natuurhistorisch Genootschap in Limburg 44: $1-188$.

Mulder, E.W.A., Bardet, N., Godefroit, P. \& Jagt, J.W.M., 2000. Elasmosaur remains from the Maastrichtian type area, and a review of latest Cretaceous elasmosaurs (Reptilia, Plesiosauroidea). Bulletin de l'Institut royal des Sciences naturelles de Belgique, Sciences de la Terre 70: 161-178.

Robbins, J.A., Ferguson, K.M., Polcyn, M.J. \& Jacobs, L.L., 2008. Application of stable carbon isotope analysis to mosasaur ecology. In: Everhart, M.J. (ed.): Proceedings of the Second Mosasaur Meeting. Fort Hays Studies Special Issue 3: $123-130$.

Schulp, A.S., 2005. Feeding the Mechanical Mosasaur: what did Carinodens eat? Netherlands Journal of Geosciences 84: 345-357.

Schulp, A.S., 2006. On Maastricht Mosasaurs. Publicaties van het Natuurhistorisch Genootschap in Limburg 45: 1-140.

Schulp, A.S. \& Jagt, J.W.M., 2015. New material of Prognathodon (Squamata, Mosasauridae) from the type Maastrichtian of the Netherlands. Netherlands Journal of Geosciences 94: 19-21.

Schulp, A.S., Polcyn, M.J., Mateus, O., Jacobs, L.L. \& Morais, M.-L., 2008. A new species of Prognathodon (Squamata, Mosasauridae) from the Maastrichtian of Angola, and the affinities of the mosasaur genus Liodon. In: Everhart, M.J. (ed.): Proceedings of the Second Mosasaur Meeting. Fort Hays Studies Special Issue 3: 1-12. 
Schulp, A.S., Vonhof, H.B., van der Lubbe, J.H.J.L., Janssen, R. \& van Baal, $\boldsymbol{R} . \boldsymbol{R} .$, 2013. On diving and diet: resource partitioning in type-Maastrichtian mosasaurs. Netherlands Journal of Geosciences 92: 165-170.

Sørensen, A.M., Surlyk, F. \& Lindgren, J., 2013. Food resources and habitat selection of a diverse vertebrate fauna from the upper lower Campanian of the Kristianstad Basin, southern Sweden. Cretaceous Research 42: 85-92.

Strganac, C., Jacobs, L.L., Polcyn, M.J., Mateus, O., Myers, T.S., Salminen, J., May, S.R., Araújo, R., Ferguson, K.M., Olímpio Gonçalves, A., Morais, M.-L., Schulp, A.S. \& da Silva Tavares, T., 2015. Geological setting and paleoecology of the Upper Cretaceous Bench 19 Marine Vertebrate Bonebed at Bentiaba, Angola. Netherlands Journal of Geosciences 94: 121-136.
Van Baal, R.R., Janssen, R., van der Lubbe, H.J L., Schulp, A.S., Jagt, J.W.M., \& Vonhof, H.B., 2013. 0xygen and carbon stable isotope records of marine vertebrates from the type Maastrichtian, The Netherlands and northeast Belgium (Late Cretaceous). Palaeogeography, Palaeoclimatology, Palaeoecology 392: 71-78.

Vonhof, H.B., Jagt, J.W.M., Immenhauser, A., Smit, J., van den Berg, Y.W., Saher, M., Keutgen, N. \& Reijmer, J.J.G., 2011. Belemnite-based strontium, carbon and oxygen isotope stratigraphy of the type area of the Maastrichtian Stage. In: Jagt, J.W.M., Jagt-Yazykova, E.A. \& Schins, W.J.H. (eds.): A tribute to the late Felder brothers - pioneers in Limburg geology and prehistoric archaeology. Netherlands Journal of Geosciences 90: 259-270. 